\title{
A ética das intervenções nos genomas
}

\section{The ethics of genome interventions}

\author{
César Koppe Grisólia \\ Universidade de Brasília, Brasília, Distrito Federal, Brasil. \\ grisolia@unb.br
}

Resumo: Os recentes avanços da biotecnologia genômica, tanto na área agrícola como na médica, tem causado controvérsias nos mais diferentes segmentos da sociedade. Há grande preocupação com os riscos ambientais e à saúde humana advindos do uso extensivo das plantas transgênicas, bem como das aplicações médicas de produtos derivados de organismos transgênicos. Muitos cientistas levantam questionamentos éticos pelo modo em que essa tecnologia interfere nos genomas dos organismos, modificando uma de suas características mais intrínsecas, a hereditariedade. Atualmente, com os novos conhecimentos sobre os mecanismos genéticos do envelhecimento, surgem propostas moralmente questionáveis de interferência no processo biológico natural do envelhecimento, como dietas de restrição calórica, uso exagerado de compostos anti-oxidantes e inclusive técnicas de intervenção no genoma para modificação de genes. A importância atual da gerontologia e da genética do envelhecimento está diretamente associada ao aumento da expectativa de vida das populações. Com isso, doenças típicas dos idosos, como Mal de Alzheimer, câncer e doenças cardiovasculares, ganham importância epidemiológica. O conhecimento dos mecanismos do envelhecimento pode levar a novas propostas terapêuticas para essas doenças, propiciando uma melhor qualidade de vida para as populações idosas, e não para tentar reverter um processo biológico natural, ou mesmo vender falsamente o elixir da juventude.

Palavras-chave: Biotecnologia. Envelhecimento. Ética. Genoma. Transgênicos.

\begin{abstract}
Plant biotechnology recently becomes the focus of heated controversy and media attention around world. The most obvious concerns have centered upon possible effects on the environment and on human health. Genetic modification of animals has arising serious concerns about the animal suffering. The concerns are divided into three main categories: animal welfare, animal integrity and relating to human and environmental issues. Bioethicists are currently expressing criticism to the ethical and social consequences of various research initiatives in the biotechnology applied to anti-aging interventions. In particular, they are reacting to research programs related to regenerative medicine, stem-cell therapies and effects to mimic of caloric
\end{abstract}




\section{Revista Brasileira de Bioética}

reduction. Gerontologists, Geneticists, Bioethicists and Policy-makers need to better protect citizens from potentially harmful, non-therapeutic and often costly products. If the life expectancy rate continues to increase gradually in developed nations, pension plans, retirement ages and social welfare schemes can be all adjusted to acknowledge evolving circumstances. Aging is not a disease and them cannot be cured. Advances in the genetic of old age will undoubtedly arise new therapies to prevent or cure specific age-associated diseases and not to reveal the elixir of youth.

Key words: Biotechnology. Aging. Ethics. Genome. Transgenics.

A partir do conhecimento e domínio da tecnologia genômica, o homem adquiriu a capacidade de manipular os genomas de todas as espécies, o que significa alterar as suas características somáticas e hereditárias, as quais foram adquiridas ao longo de todo um processo de evolução biológica. Tais alterações são feitas com objetivos antropocêntricos, isto é, de inserir nas espécies novas características genéticas de acordo com o seu próprio interesse, desprezando quaisquer conseqüências às espécies modificadas geneticamente. Os debates sobre as complexidades das pesquisas genéticas têm atraído a atenção pública da comunidade científica e da imprensa, principalmente após a conclusão do Projeto Genoma Humano e do desenvolvimento dos organismos geneticamente modificados. A possibilidade de manipulação dos genomas de plantas e animais tem levantado sérias preocupações com a ética nas pesquisas nas áreas agronômicas e médicas, respectivamente. Tais debates abordam questões religiosas, culturais, políticas, filosóficas e legais. O desafio que se tem agora é de como enfrentar e encontrar soluções para os conflitos de advindos dessa nova era da ciência.

\section{A modificação genética viola valores intrínsecos?}

Desde o estabelecimento dos mecanismos da hereditariedade por Mendel, em 1860, sabe-se que as características hereditárias são herdadas em blocos ao acaso e que certa porcentagem da descendência herda determinadas características. Sabe-se, também, que o modo de expressão de um gene dentro de uma célula define a sua fisiologia. 
Desde que o homem passou a entender as bases do melhoramento genético de plantas e animais, baseados nos princípios da genética mendeliana e quantitativa, vem modificando o perfil genético de muitas espécies de plantas e animais de acordo com os mais variados interesses. Esse processo tem sido tão acentuado, que determinados organismos resultantes de programas intensos de melhoramento genéticos perderam suas características selvagens e não conseguem mais se reproduzir livremente na natureza.

Com a entrada na era da biotecnologia genômica esses processos de modificação genética atingem outras dimensões. A biotecnologia genômica aborda os organismos de forma reducionista, pois não observa seu genoma ou o organismo como um todo e suas interações com o meio, mas somente a nova característica adquirida após a transformação genética. Não há consideração sobre as conseqüências da modificação genética e sobre as novas formas de interações desse organismo geneticamente modificado com os outros seres da mesma espécie, bem como em relação às suas interações ecológicas. A questão ética que se levanta é se a modificação genética viola ou não a integridade biológica do organismo. Alguns cientistas argumentam que aquelas modificações genéticas que não acarretam perda de função ou de capacidade que impediriam sua sobrevivência e reprodução, não estariam infringindo a integridade biológica.

A domesticação de plantas e animais pelo homem vem ocorrendo há centenas de anos. Atualmente, o melhoramento genético clássico, realizado por cruzamentos preferenciais e posterior seleção, e a modificação por engenharia genética, produzindo os transgênicos, tem contribuído drasticamente para acentuar esse processo de domesticação. Os organismos melhorados geneticamente, bem com os transgênicos, tornam-se bastante diferentes dos seus parentes selvagens. O melhoramento genético clássico consiste em introduzir características de interesse para o homem. Como exemplos podem ser citadas a maior produtividade, maior resistência ao ataque de pragas, resistência a seca etc.

Esse melhoramento ocorre quando o pesquisador consegue combinar em um organismo um pool de genes que lhes dá características de interesse, associado com a menor quantidade possível de genes desvantajosos, que são aqueles que diminuem a adaptabilidade do 
organismo, isto é, genes que aumentam sua carga genética. O processo de produção de transgênicos, com as técnicas que conhecemos atualmente, produz seu efeito desejável, isto é, o transgênico adquire características genéticas novas de acordo com o gene inserido. Entretanto, o processo de inserção altera a expressão dos genes do genoma que recebeu a inserção, podendo originar novas mutações, gerando carga genética e aumentando a vulnerabilidade do transgênico.

Assim, ao compararmos os dois processos, constata-se que ambos os mecanismos geram aumento de carga genética, que diminui a capacidade adaptativa e aumentam as vulnerabilidades desses organismos em relação ao meio em que eles vivem. Assim, se ambos os processos são responsáveis pelo aumento de vulnerabilidade, não estariam violando a integridade genética desses organismos? (1).

\section{O que significam os outros seres para o homem? Para que são pro- duzidos e modificados geneticamente?}

Nos processos de domesticação de seres animais e vegetais para atender às necessidades humanas, não se dá importância sobre o que eles significam ou sobre o que eles são, mas, sim, sobre o que eles passam a significar para o homem após a transformação genética. Assim, a transformação genética representa um tratamento altamente reducionista. O melhoramento genético clássico estreita a base genética pois reduz drasticamente a variabilidade genética, responsável pelo aumento de vulnerabilidade e perda de adaptabilidade ao seu ecossistema, perda de capacidade adaptativa às modificações ambientais e perda da capacidade de explorar e adaptar-se a novos ecossistemas. Isso representa mecanismos anti-evolutivos. Olhando por outro ângulo, ambas as modificações genéticas ocorreram para aumentar a produção de alimento para a humanidade, implicando na sua sobrevivência e expansão sobre o planeta. Daí, questiona-se até onde o homem pode violar os valores intrínsecos de outros seres em função da sua própria sobrevivência?

\section{A ética das interferências no genoma humano}

A microinjeção de genes em um ovo recém fertilizado significa um ato de violação ao patrimônio hereditário ou mais um dos mara- 
vilhosos exemplos da capacidade investigativa do homem para entender o funcionamento da natureza? Antes da era genômica e do seqüenciamento do genoma humano, o conhecimento da base genética de muitas doenças hereditárias estava restrito a algumas doenças genéticas clássicas, principalmente àquelas de origem monogênica. Com o avanço da biologia molecular e das técnicas de diagnóstico molecular foram identificados centenas de genes associados aos mais diferentes tipos de doenças, as quais não se atribuía anteriormente um componente genético. Com isso, muitos esquemas terapêuticos levam agora em consideração o fato de existir um componente hereditário. A técnica do DNA microarray mede a expressão simultânea de muitos genes, podendo assim dar um perfil da atividade gênica, com informações valiosas para o diagnóstico de muitas doenças, bem como para a prevenção ou cura de um amplo espectro de doenças genéticas. Por outro lado, essa técnica levanta uma série de preocupações éticas, pois é capaz de traçar um perfil genético dos indivíduos e assim detectar as suscetibilidades genéticas, detectar as predisposições aos diferentes tipos de câncer, as predisposições às doenças cardiovasculares, às doenças crônico degenerativas e outras vulnerabilidades hereditárias. A detecção de tais suscetibilidades pode levar a discriminações no emprego, no plano de assistência médica e no seguro de vida. De acordo com a Declaração Universal do Genoma Humano e dos Direitos Humanos da UNESCO (2), artigo 2, os indivíduos não podem ser estigmatizados pelo seu patrimônio hereditário e todos devem respeitá-los apesar das suas peculiaridades devido às suas diferenças genéticas. Entretanto, é uma técnica importante para a detecção precoce de certos tipos de câncer, para o diagnóstico preditivo e encaminhamento para outros testes genéticos específicos e tratamentos mais adequados. A utilização da informação genética deve ser baseada em princípios de benefício ao cidadão, mantendo o direito a privacidade e a confidencialidade, pois tem grande aplicação na genética clínica e no aconselhamento genético (3).

\section{Diagnóstico genético pré-implantação}

O diagnóstico genético pré-implantação é uma das metodologias mais questionáveis eticamente, pois pode ser usada para interferir modificando a estrutura do genoma humano. É o caso mais extremo 


\section{Revista Brasileira de Bioética}

de questionamentos éticos sobre os direitos de terceiros em programar o destino dos indivíduos através da manipulação das suas características genéticas. A manipulação genética de embriões in vitro, com a finalidade terapêutica abre a perspectiva para casais portadores de genes deletérios (heretozigotos) para certas doenças genéticas, com padrão de herança autossômica recessiva, de terem filhos saudáveis com $100 \%$ de segurança. Caso confirme alguma doença, o embrião analisado não é implantado na mãe; desse modo, ela é poupada de uma interrupção da gravidez. Entretanto, essa ferramenta pode ser usada também para introduzir genes no embrião com a finalidade de "aprimorar" determinadas características pré-estabelecidas pelos pais. Uma vez que, todo ser humano nasce com alguma imperfeição biológica, devido à herança de genes indesejáveis, que os geneticistas chamam de carga genética, eles passam assim a vida toda dependendo do auxílio, da atenção e do reconhecimento do ambiente social. As manipulações genéticas poderiam então ser utilizadas para corrigir tais imperfeições. As intervenções a fim de prevenir as doenças hereditárias, chamadas de "eugenia negativa" e as intervenções no embrião para inserir genes para adicionar ou aprimorar determinadas características seria a eugenia positiva. Esse limite entre as duas é flutuante e tênue, e é nessa dimensão de limites pouco definidos que o Estado tenta estabelecer regulamentações. A aplicação da técnica pré-implantação levanta uma séria questão: "é compatível com a dignidade humana ser gerado mediante ressalva e, somente após um exame genético, ser considerado digno de uma existência e de um desenvolvimento?" Esse tipo de pesquisa despertou o interesse de grandes investidores, pois abre a perspectiva de um mercado fantástico. Com esse mesmo raciocínio, impõe-se também a perspectiva de que a espécie humana possa controlar ela mesma a sua evolução biológica (4).

\section{O direito de uma herança genética não manipulada}

A manipulação de genes toca em questões relativas à identidade da espécie, do discernimento entre aquele que nasceu e cresceu naturalmente, daquele que foi "fabricado". Qual seria a auto-compreensão de uma pessoa geneticamente programada? Qual seria sua 
inserção na sociedade? Uma programação eugênica do patrimônio genético vai quebrar relações simétricas entre pessoas livres e iguais. Nas sociedades liberais, os mercados regidos por interesses lucrativos e pelas preferências de demandas, deixariam as decisões eugênicas às escolhas individuais dos pais, isto é, aos desejos dos fregueses e clientes.

Os defensores dessas intervenções justificam a eugenia liberal como um meio para melhorar a socialização e tentam mostrar que não existe nenhuma diferença entre a eugenia e a educação. Esse argumento vai ser usado, então, para justificar a ampliação da tutela educativa dos pais. Os pais decidem em função de suas próprias preferências, assumindo um papel de programadores, estabelecendo as capacidades e o comportamento da futura pessoa. Assim, as intervenções eugênicas ferem os direitos a uma herança biológica natural na medida em que submetem a pessoa em questão às intenções fixadas por terceiros, de modo irreversível, estabelecendo uma nova relação interpessoal, em que uma pessoa toma a decisão sobre a composição do patrimônio genético da outra (4).

A evolução do homem está próxima a inaugurar uma nova época na história da vida: uma espécie decidindo o que fazer a respeito de sua própria hereditariedade. Isso apresentará à humanidade as mais profundas escolhas intelectuais e éticas com a as quais essa já se defrontou. Ela pode, se assim quiser, alterar não apenas sua anatomia e sua inteligência mas, também, as emoções e o impulso criativo que compõem o próprio cerne da natureza humana.

\section{O dopping genético}

A transferência de genes tem demonstrado resultados satisfatórios. Pesquisas em pacientes com imunodeficiência letal, revelaram que a transferência de genes reforçou os seus sistemas imunológicos. Contudo, os efeitos colaterais adversos ainda são imprevisíveis e desconhecidos, uma vez que dois desses pacientes desenvolveram leucemia. Pesquisas com animais demonstraram que o IGF - I (fator de crescimento) pode prevenir o enfraquecimento muscular. Então, por que não usá-lo como um reforçador muscular? Inserções de genes GHRH (hormônio do crescimento) podem aumentar a massa muscu- 


\section{Revista Brasileira de Bioética}

lar e diminuir a gordura corpórea, o que seria ideal para os atletas. $\mathrm{O}$ fornecimento a camundongos de cópias extra de genes de receptores celulares, torna esses animais mais espertos para desvendar labirintos, porém mais sensíveis à dor. Uma manipulação genética, que pudesse aumentar a resistência à dor e a capacidade de superar o sofrimento, seria uma vantagem adicional para o atleta. Pode a transferência de genes mudar o talento natural de um ser humano? Provavelmente sim. Seria isso um sucesso nas competições? Possivelmente. Poderiam, então, cientistas e atletas conspirarem para o desenvolvimento de tal tecnologia? Talvez sim. Contudo, seria uma conspiração espúria.

Sabemos que já existe um pano de fundo para o dopping genético, baseado em: a) as metodologias atuais para o desenvolvimento físico e técnico dos atletas, que fazem com que suas marcas em competições atinjam um limite quase impossível de transpor; b) a grande maioria dos atletas vem de camadas sociais mais baixas e buscam no esporte a ascensão social e financeira: para muitos, essa busca não tem limites; c) o esporte tem sido utilizado como mecanismo de divulgação de ideologias políticas: países que dominam a tecnologia genômica são os mesmos que mantêm a hegemonia olímpica e política há muitos anos; d) os atletas de alto nível estão completamente atrelados à máquina desportiva, nas mãos, muitas vezes, de empresários inescrupulosos, com contratos de publicidades e exposição na mídia. Tais atletas encontram-se numa condição de vulnerabilidade, pois vão se submeter a qualquer tipo de procedimento, inclusive de manipulação genética, para honrar seus compromissos contratuais. Para isso, eles vão ter que estar sempre superando as suas próprias marcas, bem como suas lesões.

Assim, surge uma nova classe de atletas, os "bioengenheirados", bem diferentes daqueles que se desenvolveram por meio dos talentos naturais. Há então que se discutir uma ética para os jogos olímpicos e outras competições esportivas, uma vez que a tecnologia genômica determina desigualdades sobre-humanas (5). 


\section{A ética das intervenções anti-envelhecimento}

Os organismos unicelulares não morrem: eles se dividem e se renovam indefinidamente. Os seres multicelulares pagam um preço pela sua complexidade: envelhecem e morrem. Passamos nossos genes para a descendência ainda enquanto jovens. Posteriormente, nossos hormônios começam a decair e então paramos de nos reproduzir, envelhecemos e finalmente morremos. Por outro lado, nós nos perpetuamos na nossa descendência. Todos, um dia, deixamos de viver, mas também nos renovamos quando passamos nossas características hereditárias aos filhos, netos, bisnetos etc.

Como o envelhecimento é um processo contínuo, com os conhecimentos médicos e científicos atuais, o que se pode fazer é apenas retardá-lo, bem como propiciar aos indivíduos um envelhecimento com melhor qualidade de vida. Assim, gradativamente, um número maior de indivíduos vai atingir a velhice. Com isso, teremos no futuro grandes populações de idosos, mais suscetíveis às doenças crônicodegenerativas, como a arterosclerose, o câncer, o diabetes, a artrite, a osteoporose e as doenças neurodegenerativas, como mal de Alzheimer.

Para muitos, o envelhecimento vem acompanhado de queda na qualidade de vida, passando por perda da independência, perda da acuidade visual, aumento da suscetibilidade às doenças, queda na capacidade imunológica etc. Nesse quadro, o aumento da expectativa de vida e as medidas de controle de natalidade provocam acréscimo na proporção de idosos na população. Conseqüentemente, haverá a necessidade de uma ampla revisão nas instituições sociais, como as aposentadorias, os seguros médicos, os planos de pensões e até mesmo nas estruturas familiares. Cada vez mais as populações de diferentes países estão tendo acesso a estilos de vida saudáveis, com nutrição balanceada e atividade física, propiciando maior qualidade de vida. Assim, mais e mais pessoas atingem a terceira idade com saúde, postergando os males e as dificuldades da senilidade para as faixas etárias acima dos 80 anos. Muitos países europeus que passam por esse processo estão sofrendo uma invasão de jovens de outros países, pois há escassez de mão-de-obra.

A extensão da longevidade humana, com bases científicas, tem 
obtido sucesso e, ao mesmo tempo, provocado sérias preocupações sociais. As intervenções anti-envelhecimento são baseadas nos princípios da medicina regenerativa, terapias com células tronco, intervenções com as telomerases, as dietas hipocalóricas e as dietas e suplementações ricas em compostos anti-oxidantes. $\mathrm{O}$ desenvolvimento da biotecnologia e os conhecimentos das reais funções dos genes do genoma humano poderão favorecer o surgimento de manipulações genéticas, a ponto de surgirem empresas vendendo a imortalidade. Atualmente já existem organizações com esses objetivos, como a American Academy of Anti-aging Medicine e a Life Extention Foundation.

Há uma diversidade de conceitos e definições do processo de envelhecimento, como a teoria dos erros catastróficos, teoria das mutações somáticas, dos erros de sínteses das macromoléculas e falhas nas renovações das estruturas imperfeitas. As falhas nos processos de renovação das estruturas alteradas, as quais levam ao acúmulo de lesões, que vão progressivamente aumentando no organismo e manifestando-se com o envelhecimento. Vários tipos de lesões em biomoléculas importantes como ácidos nucléicos, proteínas e lipídios, ocorrem de modo completamente inevitável. São os chamados efeitos colaterais do metabolismo (6).

\section{O papel das espécies reativas de oxigênio e os radicais livres nos proces- sos de envelhecimento e as terapias com compostos anti-oxidantes}

O oxigênio é essencial à vida, porém, paradoxalmente, formas reativas de oxigênio são produzidas durante o metabolismo aeróbico normal, com potencial para causar danos ao organismo. O metabolismo do oxigênio, durante o processo respiratório, implica na transferência de elétrons resultando na formação de radicais livres como os ânions superóxido $\mathrm{O}_{2}, \mathrm{OH}$ e $\mathrm{HO}_{2}$ que atravessam facilmente as membranas biológicas; sendo extremamente reativos, atacam imediatamente as biomoléculas ao seu redor. Essas espécies reativas de oxigênio provocam peroxidação nos lipídios, modificam a estrutura primária das proteínas e do DNA e RNA. Existem muitos estudos que demonstram a associação entre o aumento do estresse oxidativo e a aceleração no processo de envelhecimento. As espécies reativas de oxigênio estão também associadas a muitas doenças degenerativas advindas do en- 
velhecimento, pois ao atuarem como radicais livres, atacam as biomoléculas comprometendo as funções celulares, enzimáticas e metabólicas, acarretando disfunções orgânicas. As macromoléculas e organelas lesadas nesse processo, não são descartadas pelo organismo e vão inexoravelmente acumulando-se lentamente como um lixo biológico, pois a falha de renovação é uma característica inerente das células e não necessariamente adquirida com a idade (7).

\section{O papel dos genes e a importância dos fatores genéticos: uma combinação de genes favoráveis}

Os genes com maior participação na longevidade são os que controlam o mecanismo de proteção do corpo contra os radicais de oxigênio, que são altamente reativos e causam danos ao DNA, nas proteínas estruturais, enzimas, hormônio e em outras biomoléculas, provocando várias de disfunções orgânicas. Indivíduos que herdam variantes desses genes (genes das enzimas superóxido dismutase, catalase e glutationa peroxidase) de alta atividade, têm seus organismos protegidos contra os danos oxidativos, retardando assim o processo de envelhecimento. Outra combinação favorável é a dos genes da apolipoproteína, envolvida no desenvolvimento do Mal de Alzheimer. Sabe-se que para esse gene há três alelos envolvidos: o A2, A3 e A4. Indivíduos homozigotos A4/A4 têm risco oito vezes maior de desenvolver Alzheimer que a população em geral, apresentando os primeiros sintomas a partir dos 68 anos. Indivíduos A3/A3 vão desenvolver esse mal a partir dos 75 anos e os com o genótipo A2/A2 são os que têm menor risco. Combinações gênicas favoráveis propiciam maior capacidade adaptativa para superar doenças, ferimentos ou o estresse.

Os experimentos com Drosophila melanosgaster (mosca das frutas) transgênicas, que receberam cópia extra do gene da enzima superóxido dismutase (SOD), mostram a influência desse gene sobre a longevidade, pois a drosófila vive cerca de 45 dias. As drosófilas transgênicas, com capacidade antioxidativa aumentada, passaram a viver até 60 dias (7). 


\section{O conhecimento da função dos telômeros e das telomerases nos processos de morte e imortalidade celular}

Nos organismos multicelulares o tempo de vida é regulado a nível celular. A limitação no número de divisões celulares é um ponto chave nos processos de envelhecimento e morte de um organismo. As células com maior capacidade de divisão são as embrionárias. Nos tecidos especializados, o número de divisões celulares já é bastante limitado; é o chamado relógio biológico. Um dos componentes desse relógio celular está nas extremidades dos cromossomos, os telômeros. Os telômeros são regiões heterocromáticas de ambas as extremidades dos cromossomos, que têm a função de protegê-los prevenindo fusões, recombinações, rearranjos estruturais com outros cromossomos nãohomólogos e que ancoram os cromossomos na matriz nuclear.

A cada ciclo celular, os telômeros perdem um segmento de cerca de 8 a 12 nucleotídeos de DNA, pois a enzima DNA polimerase, responsável pela replicação do DNA, não consegue renovar completamente o DNA na extremidade do cromossomo. Assim, a cada ciclo, as células perdem uma porção do telômero e, ao atingir um tamanho crítico, perdem a capacidade de organizar os cromossomos no seu núcleo, os quais então sofrem diferentes tipos de rearranjos, que culminam em anormalidades estruturais e numéricas, levando à senescência celular. Essa senescência é caracterizada pela diminuição e perda de funções, inibição na proliferação e encaminhamento para a apoptose, ou seja, morte celular.

Algumas células, como as germinativas, não podem sofrer esse processo, pois dariam origem a gametas deficientes. Nas células germinativas existe uma enzima que recompõe integralmente a extremidade do cromossomo após cada divisão: é a telomerase. Assim, tanto nos óvulos como nos espermatozóides, os cromossomos estão com os seus telômeros totalmente íntegros, pois somente nos tecidos gonadais o gene que codifica a telomerase está bastante ativo. Já nas células somáticas, esse gene encontra-se bloqueado (inativo). Desse modo, pode-se entender como indivíduos adultos produzem gametas, que ao serem fecundados geram embriões, que possuem as células com as maiores capacidades replicacionais (jovens). O maior exemplo do papel dos telômeros no processo de envelhecimento é o caso da 
ovelha Dolly, originada da clonagem a partir de uma célula somática de uma ovelha adulta. Dolly já nasceu com os seus cromossomos desgastados, pois não foram originados de gametas; e sim do núcleo de uma célula somática sem telomerase. Dolly teve um envelhecimento precoce e pouco tempo de vida em comparação a uma ovelha não clonada.

No coquetel de receitas e fórmulas anti-envelhecimento, surge então a reposição enzimática com as telomerases. Esse procedimento torna-se conflitante, pois sabe-se que em muitas células cancerosas o gene da telomerase está ativo. As células dos tumores não perdem fragmentos de telômeros a cada divisão, ficando praticamente imortalizadas. Como não são encaminhadas para a apoptose - morte programada devido ao envelhecimento - vão acumulando alterações genéticas e se tornando cada vez mais malignas. A intervenção nessa ordem natural traz seus riscos, nesse caso, o câncer.

\section{Desvendando os mecanismos genéticos do envelhecimento}

Há um grande número de evidências demonstrando que a longevidade está associada a fatores genéticos. Em todo processo de envelhecimento, fatores comuns e inexoráveis acontecem, como o desenvolvimento de placas neuríticas e de neurofibrilias no cérebro, que são marcas sinalizadoras do Mal de Alzheimer, bem como o desenvolvimento de inflamações nas articulações e as osteoartrites. Nessas doenças, alguns genes envolvidos já foram identificados. Certas combinações de alelos de sistemas genéticos polimórficos demonstraram o aumento de risco para o desenvolvimento precoce dessas doenças. No ambiente natural, processos como predação, fome, frio e doenças, fazem com que poucos indivíduos cheguem à velhice.

Em populações naturais, o envelhecimento não tem fator seletivo ou mecanismos adaptativos favoráveis, uma vez que o pico da capacidade reprodutiva ocorre na idade jovem e a reprodução tem fatores seletivos e adaptativos muito altos. Nos idosos, a capacidade reprodutiva está bastante diminuída. Sabe-se que a longevidade é obtida somente com alguns investimentos no metabolismo e nos mecanismos de reparo de mutações no DNA. Altas taxas de mortalidade extrínseca implicam em altas taxas de alocação de energia para a manutenção 


\section{Revista Brasileira de Bioética}

corpórea, crescimento e reprodução, em comprometimento à manutenção da integridade do metabolismo (8).

A evolução do conhecimento do processo de envelhecimento está baseada geneticamente na teoria da acumulação de mutações durante o tempo de vida. O acúmulo de mutações em populações selvagens não é perceptível, quando associado ao processo de envelhecimento. Entretanto, nas populações que transformam seu ambiente, a redução da mortalidade por fatores extrínsecos irá demonstrar o efeito da carga mutacional sobre a longevidade. Em populações naturais, os altos investimentos na alocação de energia para a manutenção das funções orgânicas, para o crescimento e reprodução, acarretam déficit de investimentos para a manutenção da integridade dos processos metabólicos requeridos para a longevidade. Com isso, fica evidente que os genes que regulam a integridade dos processos metabólicos e de reparo estão associados à longevidade. Tais genes são aqueles que codificam enzimas de reparo de mutações no DNA, que dão resistência a fatores estressantes intrínsecos e extrínsecos, codificando as enzimas anti-oxidantes e genes que codificam elementos extracelulares complexos que asseguram a síntese de macromoléculas que controlam a expressão gênica. Há um grande número de genes envolvidos no processo de envelhecimento, sugerindo que os mecanismos genéticos sejam conduzidos por diferentes sistemas como os polialélicos e os poligênicos com características complexas (8).

A pesquisa de marcadores genéticos em populações centenárias apresentou alguns genes candidatos, como os genes do sistema HLA (Human Leukocitary Antigens), apolipoteína E e o gene conversor da enzima angiostensina. A presença de determinadas combinações alélicas desses genes está associada a um menor risco para o desenvolvimento de doenças típicas da velhice, as crônico-degenerativas. Por outro lado, a identificação de mutações gênicas associadas a doenças do envelhecimento precoce como a Síndrome de Werner, em que a mutação no gene que codifica a helicase correlaciona diretamente as mutações no DNA ao envelhecimento. A helicase é uma enzima que tem função de auxiliar a replicação e reparar mutações no DNA, demonstrando que o acúmulo de lesões no DNA é um fator inquestionável no mecanismo de envelhecimento (8).

Sabe-se hoje que os mesmos genes que dão aos organismos a 
capacidade de suportar ambientes hostis, como o calor excessivo ou a escassez de alimento e água, têm o poder de fortalecer suas atividades de defesa e reparo. Ao otimizarem o funcionamento do corpo para a sobrevivência, esses genes maximizam as chances do indivíduo de superar crises. E se permanecerem ativados por tempo suficiente podem aumentar substancialmente seu tempo de vida. A identificação de uma família gênica denominada SIR (do inglês regulador silencioso de informações), que tem variantes em todas as espécies, quando presente em cópias extras aumentam a longevidade, como constatado em leveduras, nematóides, moscas das frutas e em camundongos. Descobriu-se que esse genes impedem que as células acumulem repetições excessivas de RNA ribossômico (RNAr) após cada ciclo de divisão. O excesso de RNAr altera a estabilidade funcional da célula, que não consegue replicar o próprio genoma e morre. A versão mamífera do SIR é o SIRT1, que codifica proteínas, chamadas sirtuínas, as quais removem e acetilam uma variedade de proteínas nucleares e citoplasmáticas, controlando as defesas celulares e o metabolismo.

A proteína sirtuína, codificada pelo gene SIRT1 pode interagir com muitos genes e caminhos metabólicos que afetam o envelhecimento. O resveratrol, composto presente no vinho tinto, é ativador das sirtuínas. Resultados de pesquisas, em que foi fornecido resveratrol a leveduras, nematóides e moscas, que possuem o gene SIR2 em funcionamento, mostram aumento no tempo de vida em $30 \%$. O mesmo fenômeno acontece ao submeter tais organismos a uma dieta de intensa restrição calórica. A intepretação mais simples é que a restrição calórica e o resveratrol ativam o gene SIR2. O melhor entendimento das vias bioquímicas desse mecanismo vai permitir desenvolver medicamentos à base de sirtuínas, para os tratamentos de Alzheiner, diabetes, câncer e doenças cardíacas e, com isso, os indivíduos com saúde também vão viver bem mais (9).

O entendimento dos mecanismos de envelhecimento pode levar ao estabelecimento de propostas científicas para extensão da longevidade. As pesquisas que estão sendo conduzidas nesse sentido apontam para as seguintes direções: a) identificação dos genes e sistemas genéticos envolvidos; b) medidas profiláticas para evitar o acumulo de mutações; c) intervenção com medicamentos; d) modificação no estilo de vida e comportamento; e) seleção natural; e f) seleção artificial. 


\section{Revista Brasileira de Bioética}

Com o conhecimento completo do genoma humano e o aprimoramento das técnicas de terapia gênica por meios de manipulação genética, vamos ter em mãos instrumentos poderosos de intervenção para expandir o tempo de vida, seja incrementando aqueles genes ligados à longevidade, ou reparando os ligados às doenças crônico-degenerativas. Se tais processos realmente irão expandir o tempo de vida, só o futuro poderá nos dizer. Entretanto, um outro objetivo também será atingido: a melhoria da qualidade de vida na velhice. Sabe-se que a genética corresponde a uma parte desse processo, pois a identificação de que fatores não-genéticos, como a nutrição e exercícios físicos, também têm contribuição importante. Assim, as combinações das interações gene-ambiente e gene-estilo de vida, apresentam-se como a melhor receita de longevidade com qualidade.

Comparando-se com as outras espécies animais, é na população humana que se encontram os maiores grupos de indivíduos que atingem a velhice. Mesmo vivendo em ambiente não-natural, a seleção natural não parou, mas modificou-se. Novas forças seletivas vão atuar sobre esse processo, como o surgimento de novos genes deletérios que serão mantidos devido às intervenções médicas, os quais irão aumentar em freqüência, contribuindo para afetar negativamente os mecanismos de extensão do tempo de vida. Isto é, com o progresso da medicina, genes deletérios seriam mantidos artificialmente nas populações, aumentando sua carga genética, e refletindo em processos degenerativos da velhice. O efeito final dessas alterações sobre a regulação do tempo de vida do homem é difícil de se predizer; entretanto, merece séria consideração.

Hoje, sabemos que a seleção artificial para a extensão do tempo de vida nas moscas das frutas, produziu resultados de acordo com as expectativas. No entanto, isso não significa que tais resultados sejam factíveis e éticos nos seres humanos. O conhecimento dos mecanismos bioquímicos, genéticos e fisiológicos do envelhecimento faz sentido ético quando aplicado com a intenção de desenvolver novos procedimentos terapêuticos para aliviar os males das doenças associadas à velhice. Tal conhecimento contribui para entender como prevenir a ocorrência dessas doenças e nas pesquisas sobre suas causas, e não simplesmente com a única intenção de se estender o tempo de vida.

Também, não seria ético pesquisar fórmulas ou o "elixir da juven- 
tude" somente para atender os anseios do homem de manter-se jovem ou com finalidades comerciais. Há ainda um longo caminho de pesquisas genéticas e a opinião pública deve discernir e aprovar aquelas pesquisas que objetivarem apresentar novos conhecimentos que tragam melhorias para a qualidade de vida para as pessoas idosas, ao invés das desenvolvidas exclusivamente para explorar uma das mais imperiosas ansiedades humanas, a perda progressiva da juventude.

\section{Uma análise do ponto de vista evolutivo}

Evolutivamente, o não-envelhecimento não manteria os indivíduos e, portanto, as espécies, indefinidamente. Pelo contrário, é um fator anti-evolutivo, pois impede a ocorrência de mecanismos adaptativos às variações ambientais, colocando as espécies em risco de extinção. Isto significa muitos indivíduos idosos em relação aos jovens, ou seja, estagnação evolutiva.

Pelas leis da natureza, somos todos descartáveis após os 25 anos, uma vez que a reprodução acontece em plena juventude e maturidade sexual. Assim é cumprida a função de passar adiante o que recebemos dos nossos pais. Ao contrário, a evolução é o ponto chave para a manutenção da vida, pois atua sobre as espécies em detrimento dos indivíduos. Desse modo, o desenvolvimento da medicina antienvelhecimento mostra o desconhecimento dos processos biológicos da natureza, bem como nossa ingenuidade. O envelhecimento não é uma doença, portanto não deve ser curado.

Nossos organismos estão preparados para se manterem saudáveis e lutar contra as doenças. Essa homeostase e sofisticação endógena trabalha a nosso favor. Com o passar do tempo, nosso organismo cumpre etapas de um processo biológico natural, em que acumulamos sinais que refletem as etapas cumpridas. Caso venhamos a adotar procedimentos para reverter essa ordem biológica e contrariar a homeostase relativa a cada etapa da vida, nós estaríamos trocando um indivíduo idoso saudável por um jovem doente. Assim, qual dessas duas pessoas viveria mais? Provavelmente o jovem doente, pois estaria mais bem equipado para lutar e se recuperar das doenças, ao menos teoricamente. Uma vez que, a luz dos conhecimentos atuais, não se consegue reverter o envelhecimento, o conhecimento do processo 


\section{Revista Brasileira de Bioética}

contribui para que sejamos idosos mais saudáveis.

A ciência promete que as mais antigas fantasias humanas serão finalmente realizadas. A doença, a velhice, a escassez e a pobreza serão abolidas e a espécie se tornará imortal. Como o cristianismo do passado, o moderno culto da ciência vive da esperança de milagres. Mas pensar que a ciência pode transformar a sorte humana é o mesmo que acreditar em magia. O culto à imortalidade tecnológica não desapareceu. Está vivo hoje em países capitalistas mais avançados. Na Califórnia, Estados Unidos da América do Norte, há organizações que oferecem uma ressurreição tecnológica a cadáveres congelados. Prometem que a criogênese, tecnologia de congelar tecidos vivos e mais tarde aquecê-los de volta a vida, nos tornará imortais. Talvez, de uma maneira ou de outra, isso venha a ser possível. O problema final da promessa criogênica não é que exagera os poderes da tecnologia. É que as sociedades que acreditam nessas promessas de imortalidade tecnológica são, elas mesmas, mortais. Imortalistas tecnológicos imaginam que a sociedade que existe hoje durará para sempre. $\mathrm{Na}$ verdade, quando chegar o tempo em que esteja disponível a tecnologia para trazê-los de volta, os mortos congelados há muito terão derretido; guerras e colapsos econômicos terão devastado os mausoléus criônicos nos quais eles silenciosamente aguardam uma ressurreição. A ciência então promete o que a religião sempre prometeu - libertarnos do nosso destino final (10).

\section{Uma análise social}

A expectativa de vida do homem moderno está muito além daquela do homem de dois séculos atrás, que por sua vez está além do homem da Idade Média e do homem da pré-história. Os estudos com fósseis mostram que as estruturas populacionais pré-históricas eram do tipo estacionárias, isto é, com uma taxa de crescimento perto do zero, pois havia muita mortalidade infantil e expectativa de vida muito curta. É difícil ter-se uma metodologia acurada para avaliar a expectativa de vida da humanidade em cada etapa da sua evolução. A partir do surgimento do Homo sapiens, entretanto, é certo que essa expectativa foi aumentando gradativamente e que após a Revolução Industrial esse aumento tornou-as ainda mais acentuado. 
A partir de 1750, surgiram métodos mais acurados de avaliação da evolução da expectativa de vida do homem, bem como dos fatores causais de mortalidade. Adotando-se a Revolução Industrial como um marco nesse processo, verifica-se que a partir de 1750 a expectativa de vida do homem triplicou, devido principalmente a redução na mortalidade infantil, fazendo com que mais crianças passassem a atingir a vida adulta, por meio do controle de epidemias e das doenças infecciosas. Atualmente, a expectativa de vida não aumenta somente nos países industrializados, mas no mundo todo. Recentemente, outros fatores passaram a contribuir mais intensamente nesse processo, como a redução de morte por doenças cardiovasculares a partir do controle da hipertensão arterial, das taxas de colesterol e dos derrames cerebrais. Associado a isso, tem-se também a diminuição do número de fumantes, a melhoria dos métodos de diagnósticos médicos e novos medicamentos. Desse modo, a intervenção terapêutica teve um papel preponderante na redução da mortalidade dos indivíduos acima de 45 anos. A conjunção de fatores como avanço das ciências médicas, mudanças na dieta e nos hábitos de vida, têm elevado a expectativa de vida de algumas populações para acima dos 70 anos.

As estruturas familiares modernas modificaram-se, uma vez que a mulher entra no mercado de trabalho em igualdade de condições com o homem. A maternidade e os cuidados com os filhos, também não passam a constituir uma dificuldade que impeça seu desenvolvimento e atuação profissional. Essa estrutura da família de classe média assalariada, que joga os casais jovens para o mercado de trabalho e, ao mesmo tempo, provoca a aposentadoria precoce dos seus pais, proporciona uma relação neto-avô com uma intensidade e duração que não havia antes na história do Homo sapiens. Hoje, os avós convivem com os netos por muito mais tempo, o que não ocorria no passado, devido ao aumento da longevidade e ao modo de vida das famílias. Em certas famílias, os netos passaram a conviver mais com os avós do que com os próprios pais. Conforme a longevidade foi aumentando, a sociedade também se adaptou a essa mudança drástica nas proporções das faixas etárias (11). 


\section{O desenvolvimento de áreas da ciência voltadas ao conhecimento dos processos biológicos do envelhecimento e a busca incessante por terapias anti-envelhecimento}

O entendimento desses processos deve ser conduzido em bases científicas, pois não há imunização contra o envelhecimento. Quase todos aqueles que dizem ou apresentam propostas de prolongamento da vida são charlatões que querem vender alguma coisa. A história apresenta ao longo dos séculos os mais variados exemplos de remédios ou procedimentos recomendados contra o envelhecimento, como: dormir com virgens e respirar o mesmo ar que elas respiram; beber o sangue de jovens viris; tomar injeções de testículos de cães; o elixir dourado preparado pelos chineses; compostos à base de algas marinhas; compostos preparados com células de fetos de ovelhas, porcos, coelhos etc.

O que é importante na busca pelo entendimento desses processos é sua aplicabilidade no sentido de ajudar a protelar o surgimento de enfermidades e a permanecer mais saudável por mais tempo. A postura ética da ciência é a de esclarecer o público de que os produtos e procedimentos apregoados contra o envelhecimento em clínicas de longevidade e outros lugares não têm eficácia cientificamente comprovada, podendo até serem danosos para a saúde (12).

Sabe-se, hoje, que o estilo de vida saudável está associado ao prolongamento do tempo de vida. Comer e beber moderadamente, não fumar, fazer exercícios físicos regularmente, evitar situações de estresse e dormir bastante não vai nos manter jovens, mas pode impedir os piores problemas que vem com a idade. Cada vez mais, aprofundamos o conhecimento dos processos biológicos de envelhecimento e a cada nova descoberta surgem propostas terapêuticas ou de conduta que contribuem para a longevidade. Paradoxalmente o progresso das ciências médicas, indiretamente, conduz os indivíduos à velhice. Propiciando uma vida mais longa e saudável, estaríamos contribuindo para aumentar a população de idosos e as doenças degenerativas inevitáveis da senilidade. Assim, as pesquisas sobre a longevidade precisam caminhar com as investigações de como cuidar de uma população centenária, pois as pessoas mais idosas poderão passar anos de vida em um estado totalmente dependente e debilitante. 


\section{Referências}

1. Bruce, A; Whitlaw, A \& Bruce, D. Does genetic modification violate intrinsic values? Trends in Biotechnology 20 (12), 2002. pp. 488-9.

2. UNESCO. The Universal Declaration on the Human Genome and Human Rights: from theory to practice, 2000.

3. Murray, A \& Clarke, A. The ethics of populations screening. Current Paediatrics 12, 2002. pp. 447-52.

4. Harbenas J. O futuro da natureza humana: a caminho de uma eugenia liberal. São Paulo, Ed. Martins Fontes, 2004.

5. Murray, TH. Ethics watch: an olympic tail. Nature Reviews - Genetics 4, 2003. p. 494.

6. Terman, A \& Brunk, UT. Aging as a catabolic malfunction. The International Journal of Biochemistry \& Cell Biology 36, 2004. pp. 2365-75.

7. Turner L. Biotechnology, bioethics and anti-aging interventions. Trends in Biotechnology 5, 2004. pp. 219-21.

8. Kirkwood TBL. The genetics of old age. In: Burley, J \& Harris, J. (eds.). A companion to genethics, London: Blackwell Publishing, 2002. pp. 43-50.

9. Sinclair, DA \& Guarente, L. Desvendando os segredos dos genes da longevidade. Scientific American Brasil 47, 2006. pp. 40-6.

10. Gray, J. Cachorros de palha - reflexões sobre humanos e outros animais. Rio de Janeiro, Editora Record, 2002.

11. Wilmoth, JR. Demography of longevity: past, present and future trends. Experimental Gerontology 35, 2000. pp. 1111-29.

12. A ciência em busca da juventude. Scientific American Brasil. Edição Especial, número 6, 2005. pp. 9-97.

Recebido em 15/09/2006. Aprovado em 20/10/2006. 